\title{
Transnacionalismo e Gnose Liminar em “As Brasíadas” (2013), de Diana Menasché
}

\author{
Transnacionalism and Liminal Gnosis in "As Brasíadas" (2013), \\ by Diana Menasché
}

\section{Leoné Astride Barzotto}

Universidade Federal da Grande Dourados - UFGD - Mato Grosso do Sul - Brasil

\begin{abstract}
Resumo: Este artigo faz uma análise pós-colonial do poema "As Brasíadas", de Diana Menasché. Este poema é parte da obra Traz o esqueleto que eu ponho a carne (2013) e, por meio dele, a autora faz uma releitura, à luz da contemporaneidade, da canônica obra de Luís de Camões, Os Lusíadas. Apesar de manter a forma do épico de Camões, Menasché atualiza o discurso e revela aspectos de transnacionalismo e de gnose liminar em sua escrita. Assim, eu proponho expor que, enquanto escritora brasileira imigrante nos Estados Unidos, ela constrói uma literatura híbrida e transfronteiriça, marcada pelo trânsito de saberes interamericanos e pela proposta de uma gnose (epistemologia) liminar que revela o vínculo entre nações e práticas culturais emancipatórias.
\end{abstract}

Palavras-chave: Transnacionalismo. Gnose Liminar. As Brasíadas. Diana Menasché. Literatura Pós-Colonial.

Abstract: This article brings a Post-Colonial analysis of the poem "As Brasíadas", written by Diana Menasché. The poem is part of her book Traz o esqueleto que eu ponho a carne (2013) and, through it, the author develops a re-reading process through a contemporary perspective and based on Luís de Camões' work, Os Lusíadas. Even though she maintains Camões' epic format, Menasché upgrades the discourse and reveals aspects of transnacionalism and liminal gnosis in her own writing. Thus, I try to demonstrate that, as a Brazilian and as an immigrant in the United States, she builds a hybrid and transborderer literature, highlighted by the inter-American transit of knowledge and by the proposal of a liminal gnosis (epistemology) which shows the bonds among nations and emancipatory cultural practices.

Keywords: Metaphor. Transnacionalism. Liminal Gnosis. As Brasíadas. Diana Menasché. Post-Colonial Literature. 


\section{Perspectivas Basilares}

A cultura, de qualquer sociedade, é como uma esponja que filtra todas as transformações sociais da mesma, retendo determinados aspectos e deixando outros se diluírem. Nesta condição de meio determinante, de filtro, de força motriz, a cultura é, por si só, a melhor representação de uma dada comunidade, pois dela incorpora todos os traços. Neste prisma, a Literatura, como importante artefato cultural igualmente revela aspectos inerentes a grupos sociais tais e também os representa. Por esta razão, entendo que o texto literário, sobretudo aquele que traz em si cargas pós-coloniais de observação, tem peculiar relevância quando se trata de pensar dada comunidade ou nação, assim como quando se pretende compreender os indivíduos desta comuna cultural e seus atos. Aqui, portanto, cabe-me pensar a comunidade de imigrantes brasileiros nos Estados Unidos da América e, dentro dela, investigar a escrita literária da escritora brasileira e, também ela migrante, Diana Menasché, a fim de perceber o Brasil fora do Brasil num intercâmbio interamericano de saberes culturais. Dentro deste panorama, a imigração brasileira nos Estados Unidos da América é eleita como matriz de estudo conceitual para o aporte literário. De raiz etimológica latina - immigrare ${ }^{1}$ contempla, basicamente, aquele que deixa seu país de origem para entrar em um país estrangeiro e, ali, habitar. Diante de todas as expressões de deslocamentos humanos, a imigração, a diáspora e o exílio surgem com motivações e nuanças próprias.

Neste evidente contexto de trânsito, os impactos do imperialismo de outrora e da força da globalização na atualidade resultam, exatamente, no efeito óbvio que as hegemonias (neo)colonialistas negam aceitar, ou seja, a hibridização de todos os círculos socioculturais atuais, posto que as metrópoles centralizadoras do poder estão invadidas e modificadas por movimentos migratórios sem precedentes, com sujeitos advindos das mais diversas partes do planeta e, neste escambo humano, o

\footnotetext{
${ }^{1}$ http://www.dicionariodoaurelio.com
}

hibridismo - em todas as suas facetas - atinge seu clímax, configurando comportamentos e decisões em todo o globo, desde o consumo até as mais novas tendências e manifestações artísticas, da moda à nova mídia, do saber adquirido ao fazer cotidiano. Em suma, centros e margens já não estão mais tão bem delineados, visto que há 'centros' nas margens e 'margens' nos centros (ACHUGAR, 2006). A preservação do sujeito imigrado, na condição de deslocado ou 'sem-lugar', dá-se de forma transnacional e tradutória: transnacional porque retém as experiências e as memórias do lugar de origem; e tradutória porque demanda uma releitura dos símbolos tradicionais culturais que formam as novas culturas, adaptando-se às divergências. No entanto, através de uma vertente transcultural, tal desafio deixa transparecer o lado produtivo dos conflitos intercomunitários, cujos valores, resultantes da negociação entre ambas as culturas, apontam para algo novo, sendo que esta nova interpretação não pertence a nenhuma cultura em particular.

Logo, no que tange a questão da identidade, a memória (individual e coletiva) é precioso aparato, uma vez que, ao imigrar, o indivíduo se afasta de sua base estrutural de origem e, obviamente, ao diminuir o contato com sua comunidade a sua memória individual fica mais fragilizada, posto que está longe das memórias coletivas que 0 identificam como comunidade ou nação. Se as memórias são fragmentadas, é no coletivo que os fatos se reavivam e as culturas sobrevivem. Como, então, manter uma proposta de pertencimento cultural diante do desafio de esquecimento e exclusão que a imigração traz como ameaça? Para Benedict Anderson (2008, p. 34) as comunidades "imaginadas" se fundam em um senso de desejo, de progressão, independentemente das desigualdades e da exploração efetivas que possam existir dentro delas, a nação é sempre concebida como uma profunda camaradagem horizontal. Contudo, é necessário considerar que as comunidades imaginadas pelos imigrantes em solo estrangeiro divergem daquelas imaginadas pelos sujeitos locais,

Significado de Imigrar: v.i. Estabelecer-se numa terra que não é a sua. (Antôn.: emigrar.) 
os quais têm seus próprios desejos e projeções para as suas comunidades imaginadas e em consonância com sua ideologia de nação; neste item entram aspectos de toda a natureza que configuram as diversas nações com as nuanças que lhes são típicas; como por exemplo a concepção de nação russa há de divergir da concepção de nação brasileira, de nação francesa e assim por diante. Desta forma, como agregar todos estes desejos comunitários e viver em harmonia em solo estranho? Proponho, então, uma suposta solução-resposta: a capacidade de organização comunitária estreita elos de suporte entre os pares no exterior, seja por motivação étnica, religiosa, política, classista ou, ainda, ideológica e tal organização responde às questões supracitadas numa espécie de compensação de 'estar longe de casa', pois somente em uma organização sociocultural comum os indivíduos têm a condição de valorar o senso de pertencimento cultural e, mais do que isso, sentiremse parte de algo maior do que si mesmos. A título de exemplificação, um evento que concretiza e reforça tal proposição é o Brazilian $D a y^{2}$, grande manifestação cultural que se iniciou nos Estados Unidos, fazendo parte, atualmente, dos calendários oficiais em vários países mundo, sobretudo naqueles com grande concentração de imigrantes brasileiros. Sobre esta gigantesca aglomeração humana em festa (fora de casa), a antropóloga norte-americana, especialista em imigração brasileira nos Estados Unidos da América, relata que

...milhares e milhares de brasileiros, exuberantes em seus trajes verdes e amarelos, misturam-se a americanos locais aficionados pelo Brasil e turistas estupefatos - estrangeiros e domésticos - querendo saber o que é aquilo em que acabam de se meter. O festival é uma imagem atraente e instantânea de uma das ondas mais recentes e praticamente veladas de imigrantes para os Estados Unidos. Dezenas de milhares de brasileiros de todos os recantos do nordeste dos Estados Unidos vão em massa ao evento anual - a maior celebração da etnicidade brasileira no exterior (MARGOLIS, 2013, p. 18, grifo meu).

Face ao contexto de sobrevivência e manutenção cultural do imigrante no exterior, Margolis

2 Cf.: http://www.brazilianday.com/

Em 2014, comemorou-se 30 anos do evento em Nova lorque com o bordão "O maior evento brasileiro fora do Brasil".
(2013) e Anderson (2008) trazem constatações que se chocam entre si, mas que ao mesmo tempo interagem. Enquanto ela discute a 'invisibilidade brasileira' no Estados Unidos, ele apresenta o conceito de uma 'imagem em uníssono', o que pode 'agitar' a invisibilidade destas comunidades imaginadas no âmbito do real conflituoso. Para Anderson (2008), a língua materna é o mais forte instrumento de manutenção cultural, pois é através dela que as memórias são reavivadas e compartilhadas em coletividade para compor um status sociocultural; a língua está mais enraizada no indivíduo do que ele próprio possa imaginar e é com ela que as comunicações se efetivam e todo o restante é descrito nos campos afetivo, social, econômico e familiar, compondo o todo da sua etnicidade. Para Margolis (2013), a etnicidade imigrante é fragmentada pela forte pressão da própria condição da migrância. Consequentemente, é preciso reconhecer o potencial da Literatura como representante das mais variadas etnicidades (as que se constroem, as que se complementam ou as que se aniquilam) no âmago e no fervor dos movimentos migratórios contemporâneos. Acerca da complexidade do termo 'etnicidade', discorre Eurídice Figueiredo:

A etnicidade - seja ela a raça, a cor, a religião, o gênero (gender) - se define como uma categoria que situa o indivíduo ou o grupo social como sendo Outro. Eric Landowski (2002) mostra que o grupo de referência, associado à maioria, geralmente se vê como um grupo homogêneo; a alteridade é, assim, percebida como diferença, que tende a ser considerada uma ameaça ao bem-estar da comunidade. Esta ameaça (muito mais imaginária que real) leva à exclusão ou à assimilação do diferente: ambas as atitudes correspondem a uma não aceitação da diferença, pois a verdadeira aceitação deveria suscitar uma atitude de compartilhamento do espaço público, de maneira negociada (FIGUEIREDO, 2010, p. 10, grifo da autora; grifo meu).

Neste sentido, ao pensarmos etnicidade como marca distintiva de um sujeito/grupo, é inviável sugerir que o sujeito se desfaça de suas canções de ninar ou de suas músicas prediletas da infância, da adolescência, posto que elas podem até mesmo se 
apagar, ficar em stand by, mas qualquer gatilho poderá reavivá-las na conexão do sujeito com sua memória pessoal e afetiva, aquela de maior apreço ao ser. As afeições habitam o espaço da intimidade e da individualidade e, por isso mesmo, é que cada indivíduo seleciona (conscientemente ou não) o que acha relevante conservar para lembrar $^{3}$ ou desnecessário e pesado demais, o que deve ficar no baú do esquecimento ${ }^{4}$. Sabemos que a vida seria insuportável sem a agência e o poder do esquecimento; precisamos esquecer, inclusive e sobretudo, para lembrar e, neste vai e vem de lembranças, a língua materna exerce fundamental papel. Conforme Anderson (2008, p. 215), "Por meio desta língua, que se conhece no colo da mãe e que só se perde no túmulo, restauram-se passados, imaginam-se companheirismos, sonham-se futuros".

Por este prisma da memória individual, levada à coletividade pela emoção e pela afetividade para ressignificar o presente, é que Anderson explica seu conceito de 'imagem do uníssono', compreendido facilmente quando pensamos a respeito do fenômeno cultural avassalador Brazilian Day em Nova Iorque, a título de exemplificação. Logo, a 'invisibilidade do brasileiro' pode se tornar visível, mesmo que temporariamente, para que o grupo de referência saiba que se trata de um movimento de amor à pátria brasileira, aquela que precede todas as outras, aquela do coração, da origem, da língua materna, da memória mais viva de todas... a nutrida pela saudade ${ }^{5}$. Se os imigrantes são bem sucedidos ou não no exterior, neste momento não se considera porque o movimento arrasta a todos cujos corações são (ou desejam ser) verdes e amarelos. Para Halbwachs (2006), o indivíduo da memória está inserido em um grupo de referência, posto que a memória é elaborada em grupo, sendo antes, porém, um trabalho do sujeito. 0 Brazilian Day é, portanto, um exemplo de realização física em eco da comunidade imaginada assim como é um detonador da memória coletiva brasileira no exterior, exercendo função semelhante, numa escala

\footnotetext{
${ }^{3}$ Apego afetivo. Halbwachs (2006)
}

bem menor, ao álbum de família que revoluciona o lugar da memória no plano doméstico, conforme determina Le Goff (2003, p. 460).

Existe um tipo específico de comunidade contemporânea que apenas a língua é capaz de sugerir - sobretudo nas formas de poemas e canções. Tomemos o exemplo dos hinos nacionais, cantados nos feriados nacionais. Por mais banal que seja a letra e medíocre a melodia, há nesse canto uma experiência de simultaneidade. Precisamente nesses momentos, pessoas totalmente desconhecidas entre si pronunciam os mesmos versos seguindo a mesma música. A imagem: o uníssono (ANDERSON, 2008, p. 203).

\section{Mobilidades Culturais - Transnacionalismo e Gnose Liminar}

Habitar à distância, no caso dos imigrantes, é habitar a língua e a cultura do Outro mesmo sem ser convidado a tal; é estar no fluxo inconstante e movente do entre-lugar, habitar vários mundos em uma complexa e inusitada realidade, considerando que há os domínios doméstico e público, nos quais os imigrantes se articulam para negociar sua alteridade. No espaço privado e familiar, a língua materna costuma imperar assim como os valores trazidos da terra natal; já no espaço público, há a necessidade de maior negociação, adaptação ao meio no qual se instalou assim como aos valores que são vigentes $\mathrm{e}$ predominam no referido lugar. Para Mignolo (2003, p. 98) a tradição nada mais é que a persistência da memória. A tarefa de constante shift e readequação por parte do imigrante não é, em nada fácil, pois the exige $o$ abandono de muito daquilo que lhe constitui a fim de ser aceito no novo ambiente e, quiçá, algum dia ser considerado parte do grupo de referência. Evidentemente, a imigração pode ser um ato voluntarioso ou não e, dependendo do tipo de imigração exercida pelo indivíduo, pode haver trauma e o desejo do 'retorno redentor', conforme postula Hall (2003). Acerca da contínua (trans) formação cultural do imigrante, Hall (2003, p. 44, grifos meus) descreve que

A cultura é uma produção. Tem sua matériaprima, seus recursos, seu 'trabalho produtivo'.

\footnotetext{
4 Desapego. Idem

5 A memória coletiva como acervo de lembranças compartilhadas. Idem
} 
Depende de um conhecimento da tradição enquanto 'o mesmo em mutação' e de um conjunto efetivo de genealogias. Mas o que esse 'desvio através de seus passados' faz é nos capacitar, através da cultura, a nos produzir a nós mesmos de novo, como novos tipos de sujeitos. Portanto, não é uma questão do que as tradições fazem de nós, mas daquilo que nós fazemos das nossas tradições. Paradoxalmente, nossas identidades culturais, em qualquer forma acabada, estão à nossa frente. Estamos sempre em processo de formação cultural. A cultura não é uma questão de ontologia, de ser, mas de se tornar.

Entretanto, nem todos os imigrantes atribuem a experiência da imigração a um fardo difícil de carregar; especialmente os que desejam a ascensão social por meio do trabalho no exterior, 'fazer a América ${ }^{6}$, ou a aventura de diferentes vivências culturais. Há, deste modo, imigrantes e imigrantes. Contudo, ainda que adaptado e incluído socialmente, o imigrante sempre será um estrangeiro. Por este motivo, Sayad (1998) define o processo de imigração como um processo 'total', ou seja, um grupo de ações e decisões as quais envolvem toda as condições que levam alguém a emigrar de seu país de origem e a imigrar em uma terra alheia, desde o desenraizamento à relocação, do desejo de ir ao desejo de voltar, do sucesso ao fracasso da experiência migrante. Assim sendo, "o imigrante é 'atopos', deslocado e sem lugar" (BOURDIEU apud SAYAD, 1998, p. 11).

Até a segunda grande guerra, o Brasil não se apresentava aos olhos do mundo como uma nação que almejava enviar seus filhos para outras pátrias; emigrar não era assunto do cotidiano, imigrar para o Brasil sim. Havia, infelizmente, uma política altamente racista de branqueamento da população brasileira, com bizarros cálculos e tudo mais, engendrando o estímulo e o suporte do Estado para o envio de imigrantes europeus ao solo brasileiro. Depois da segunda guerra mundial, com a vitória dos aliados, o Brasil passa a admirar e a ver os Estados Unidos da América de forma distinta. Neste ínterim, a leva de imigrantes aumenta significantemente e o Brasil começa a delinear-se, definitivamente, como uma nação construída pela força do trabalho do imigrante.

\footnotetext{
${ }^{6}$ Ganhar dinheiro; prosperar e se instalar de forma fixa na nova terra.
}

Os imigrantes de distintas partes desejam também 'fazer a América'.

Todavia, depois do golpe militar de 1964, o Brasil passa a constituir o quadro de nações emigrantes, enviando trabalhadores de toda ordem ao exterior, os quais sufocados pela repressão e falta de liberdade procuram abrigo em nações onde a mão do Estado não censure tanto o seu povo. Não bastasse isso, o Plano Real, a hiperinflação, salários miseráveis, alta taxa de desemprego de décadas posteriores (80 e 90) fazem com que a emigração se torne, para muitos, a única projeção de futuro e de realização de sonhos. Portanto, de acordo com Margolis (Idem, p. 18), a partir de 1980, considerada a década perdida, milhares de brasileiros deixam o país devido a uma sequência de situações econômicas críticas e assoladoras. Neste contexto de caos social, intensifica-se a imigração dos brasileiros aos Estados Unidos da América, vistos então como a terra das oportunidades. Estima-se que aproximadamente $\quad 1.500 .000$ brasileiros vivam atualmente nos Estados Unidos. Destes, mais de 60\% são imigrantes ilegais, fator que dificulta a exatidão dos censos, tanto para o governo norte-americano quanto para o brasileiro. Os brasileiros imigrantes têm como destinos preferenciais, respectivamente, os Estados Unidos, o Japão e o Paraguai. Em solo norteamericano estão, notadamente, em grande número nas cidades de Boston, Nova lorque, São Francisco, Los Angeles, São Diego e em Miami. De acordo com Margolis (2013), os brasileiros costumam trabalhar no ramo da construção civil, da alimentação e na prestação de serviços em geral, como limpeza, cuidado de crianças, etc.... além da venda de artigos brasileiros, aulas de danças típicas e demais atividades que propagam o Brasil e possam render lucro. A grande maioria, ilegal, vive à sombra do medo da deportação. No entanto, os brasileiros costumam ter uma escolaridade maior que os demais imigrantes da América Latina; contudo, a maior parcela se apresenta nas estatísticas portando somente o ensino médio $^{7}$. Logo, a grande massa humana de imigrantes brasileiros com baixa escolaridade exerce funções

7 Em 2009, pouco mais de $11 \%$ dos brasileiros tinham nível superior completo; Margolis (2013, p. 82). 
que, muitas vezes, os norte-americanos não desejam exercer, recebendo salários baixos para os padrões daquele país, principalmente depois da crise econômica nos Estados Unidos, pelo endurecimento das políticas imigratórias consequentes do 11 de setembro e pela intensificação da crise imobiliária pós2008.

Sobre o assunto, Silviano Santiago (2004, p. 52), em 0 cosmopolitismo do pobre, enaltece que "Rejeitado pelos poderosos estados nacionais, evitado pela burguesia tradicional, hostilizado pelo operariado sindicalizado e cobiçado pelo empresariado transnacional, o migrante camponês é hoje o 'mui corajoso' passageiro clandestino da nave de loucos da pós-modernidade". A categorização étnica dentro do contexto de imigração internacional é igualmente um problema para os brasileiros na 'terra do Tio Sam'. "Nos Estados Unidos, por exemplo, os imigrantes brasileiros reclamam, com veemência, do fato de os norte-americanos os confundirem, de maneira sistemática, com os hispânicos, e insistem que não pertencem a essa etnia porque falam português, e não espanhol" (MARGOLIS, 2013, p. 25).

Para essa mesma autora, o transnacionalismo coopera na formação da identidade dos imigrantes longe de casa, pois faz com que mantenham os laços com a terra natal, apesar da distância. Por conseguinte, os migrantes transnacionais, como é o caso da maioria dos brasileiros, e da autora que aqui é abordada, ficam conectados a duas sociedades ao mesmo tempo, a de origem e a receptora. "O termo 'transnacional' é usado para indicar a facilidade com que pessoas, objetos e ideias fluem de lá para cá, e vice-versa, através das fronteiras internacionais" (Idem, p. 242). Por esta razão, eles preferem se autoidentificar pela nacionalidade - 'sou brasileiro'8 - e não pela categorização étnica - ‘latino ou hispânico' desenvolvida pela sociedade norte-americana. Portanto, é uma consequência natural que a comunidade brasileira de imigrantes se altere culturalmente face às inserções sociais que tem de

\footnotetext{
8 Margolis (2013) compreende que a falta de conhecimento dos norte-americanos em relação à cultura e à realidade brasileira favorece um sentimento de frustração e tristeza na comunidade brasileira dos EUA.
}

fazer fora do Brasil; ademais, modifica da mesma maneira o panorama cultural da comunidade receptora. Assim, os processos migratórios são vias de mão dupla, autênticos escambos culturais: espaços transculturais e híbridos em zonas de contato conflituosas e altamente criativas, nas quais os sujeitos inseridos saem involuntariamente modificados, ao mesmo tempo em que são modificadores destes mesmos espaços.

Por esta razão, o que está em jogo é muito mais uma questão de reação (empoderamento) do que uma questão de ação, propriamente dita. A partir da literatura pós-colonial articulo, então, uma nova lógica de produção intelectual que pensa a colonialidade do poder ${ }^{9}$ através da modernidade, porém de forma livre, visando uma interseção das histórias locais/nacionais mediante a imposição dos novos projetos globais. Tal lógica nasce no entre-lugar porque configura a especificidade de um determinado lócus de enunciação, além de fluir dentro das línguas e das culturas. Por essa mesma ótica, essa nova lógica é essencialmente híbrida e transcultural, pois é construída no fluxo das 'contaminações' todas que geram sua existência, objetivando compreender a diversidade e, principalmente, propagá-la no âmbito intelecto-social. Sendo assim, assume nova postura de 'estar no mundo' (híbrido) porque exerce a prática cultural em meio às identidades altamente intercambiantes.

Assim sendo, no sentido de pensar/produzir sem a imposição do 'outro', mas em face de sua influência, Mignolo (Idem, p. 104) descreve 'gnose liminar' como uma proposição para um outro pensamento - híbrido por essência: "uma maneira de pensar que não é inspirada em suas próprias limitações e não pretende dominar e humilhar; uma maneira de pensar que é universalmente marginal, fragmentária e aberta; e, como tal, uma maneira de pensar que, por ser universalmente marginal e fragmentária, não é etnocida". Logo, a gnose liminar é uma epistemologia das margens, neste caso, dos

9 Entenda-se o termo, nesse contexto, como tentativa contemporânea de manipulação dos mais poderosos sobre os menos favorecidos no panorama socioeconômico mundial. 
imigrantes. A partir desta perspectiva de cultura transfronteiriça e emancipadora - eu percebo a narrativa de Diana Menasché como frutífero exemplo por demonstrar efetivo intercâmbio transnacional; um transnacionalismo literário entre Portugal e Brasil, num primeiro momento, e depois cultural entre Brasil e Estados Unidos, num segundo momento. Com isso, ao analisar seu poema "As Brasíadas", desejo de antemão, desenvolver uma conscientização sociocultural à guisa do conhecimento produzido em trânsito, pois, conforme postula Rajagopalan (2003, p. $57)$ somos todos afetados pelos movimentos globais:

Queiramos ou não, vivemos num mundo globalizado. Entre outras coisas, isso significa que os destinos dos diferentes povos que habitam a terra se encontram cada vez mais interligados e imbricados uns nos outros fenômeno que vem sendo chamado de 'transnacionalização' [...] O outro lado dessa mesma moeda se chama 'desterritorialização' das pessoas - que, por motivos diversos, tornam-se, em número cada vez maior, cidadãs do mundo - e suas práticas identitárias (KRAUSE e RENWICK, 1996).

Os laços que se mantém entre familiares, amigos e negócio de uma nação para a outra, diante do vínculo de gerações em diferentes territórios, formam o capital cultural que fomenta o conceito de transnacionalismo. Similar à Margolis, a concepção de Bauböck e Faist (2010) diz que as experiências transnacionais são as geradas por tais laços entre fronteiras de múltiplas nações, os quais contestam os limites geográficos e políticos, assim como os culturais. Muito embora não seja um fenômeno novo, o transnacionalismo está sendo cada vez mais estudado ao passo que está sendo cada vez mais vivido por conta dos efeitos da globalização, dos avanços tecnológicos e da melhoria nos meios de transportes internacionais. Logo, todos estes aspectos possibilitam o aumento sem precedentes das práticas transnacionais, ou o transnational turn (BAUBÖCK; FAIST, 2010). Neste sentido, as mobilidades culturais são reflexo dessas conexões transfronteiriças e multinacionais em coerência, então, com os aspectos fundamentais do transnacionalismo, de acordo com
Lacroix (2009), que são mobilidade, espaço social fragmentado e cultura híbrida.

A escritora brasileira Diana Menasché, enquanto sujeito migrante, representa o fenômeno do transnacionalismo tal qual exposto porque elabora uma construção literária brasileira (fora do Brasil) altamente pautada pelo movimento de intercâmbios socioculturais entre Portugal, Brasil e Estados Unidos. Ela nasceu no Rio de Janeiro, onde se formou em Comunicação Social pela Pontifícia Universidade Católica do RJ; imigrou para os Estados Unidos da América, onde fez Mestrado em Letras Hispânicas pela UMass Amherst; vive atualmente em Nova lorque, onde faz doutorado na CUNY. Seu primeiro livro, Tá no sangue, foi contemplado com a Bolsa para Escritores da Biblioteca Nacional. Diana se destaca na escrita de poemas e sua prosa, assim como os poemas, tem traços marcantes de hibridismo cultural e de nuanças migratórias. Muito embora escreva sempre em língua portuguesa, a autora usa, não raro, termos em língua inglesa e em língua espanhola, refletindo sua própria experiência migrante transnacional, a qual transita em distintos universos, culturas, línguas e realidades. É típico da identidade transnacional o sentimento forte e o desejo constante em manter vínculos com a nação de origem da mesma forma que se faz com a nação de chegada, após a adaptação. Diana Menasché exerce tal sentimento de maneira destacada em seus dois livros Tá no sangue (2013) e em Traz o esqueleto que eu ponho a carne (2013); de onde extraí o poema "As Brasíadas". Além dessas publicações, a escritora mantém um blog literário denominado "O livro voador"10, o qual alimenta com inúmeros poemas e textos, informações do mundo literário e também textos críticos, desde 2007. No blog, o hibridismo linguístico é mais evidente ainda, há textos completamente publicados em língua inglesa e outros em que a autora traduz seus próprios poemas. A escrita desta autora é delineada por sentimentos universais, como amor, ódio, amizade, sofrimento, angústia, medo, existencialismo e saudades. É, igualmente, altamente crítica e influenciada pelas

10 Cf.: http://dianamenasche.blogspot.com/2007/05/o-livrovoador.html Acesso em 10 dez. 2015. 
culturas todas que a cercam neste processo de migrância e comportamento (literário) transnacional. Sobre sua conexão com a terra natal, a autora publica, em 07 de maio de 2009, o seguinte poemeto autobiográfico:

\begin{abstract}
"O corpo Brasil tá no sangue"
Então aqui estamos. Tentando entender, processar, traduzir, reconhecer essa coisa que não tem forma e que é tão eterna - a relação com o Brasil. E que não é clara, e existe quando penso ou não penso nela - mas como não penso, se cada vez que falo uma palavra em Inglês penso que o Inglês não é (ainda não é) (?) a minha língua. E o Brasil vai ficando mais denso e mais profundo conforme o tempo passa. Ele emerge de dentro e sobe para a minha cabeça assim, de repente, em imagens mais fortes que as que eu teria se estivesse lá com os dois olhos abertos. Não sei. Não sei como isso acontece. As imagens que tenho hoje são mais fortes que as que tinha quando via... O corpo Brasil no espectro da minha percepção, um contato permanente, como se estivesse na minha composição física. Uma consciência de país refeita e reassimilada, um mergulho nessa camada de memórias e redondilhas tão transcendente, tão carnal... (dianamenasche.blogspot.com, grifo meu) ${ }^{11}$.
\end{abstract}

São vários os momentos em que a escritora demostra, via poesia ou prosa, no blog ou nos livros, os meandros de uma adaptação cultural e isso, aos poucos, sedimenta e fortalece o que vem a ser suas práticas culturais e literárias transnacionais: “'Descentralização' - Estar num lugar / com vontade de estar noutro / Estar num lugar / com a cabeça estando noutro / Estar num lugar / estando noutro" $(M E N A S C H E ́, 2010)^{12}$. No entanto, meu foco de análise é o poema "As Brasíadas". Este poema é a parte inicial do livro Traz o esqueleto que eu ponho a carne (2013). Neste livro, usando de uma estratégia comum à Literatura Pós-Colonial, Diana Menasché faz releituras de textos clássicos das Literaturas Portuguesa e Brasileira; com perfeito intercâmbio entre elas e navegando o Oceano Atlântico de forma tão sutil que quase imperceptível. Sua investida literária transnacional, reforçada pela própria experiência migrante, enriquecem e ampliam as temáticas abordadas nas releituras. Ela mesma, na sua performance antropofágica de digestão literária destes

11 Cf.: http://dianamenasche.blogspot.com/search?updated$\min =2009-01-01$ T00:00:00-02:00\&updated $-\max =2010-01$ 01T00:00:00-02:00\&max-results $=14$ textos canônicos, consolida as mobilidades culturais tão profícuas e pertinentes à literatura.

A obra em questão tem a seguinte divisão: "As Brasíadas" - poema em diálogo com Os Luzíadas, de Camões, meu objeto de investigação neste artigo. Nele, a autora mantém trinta e seis estrofes com oito versos decassílabos ABABABCC. Em seguida, "Canção do enternecimento" - poema em diálogo com "Canção do Exílio", de Gonçalves Dias (com cinco estrofes, três de quatro versos em $A B C B$ e duas estrofes com seis versos ABCBDB. Todas de sete sílabas). Depois, "Vai, Vanderlei” - em diálogo com "IJuca Pirama", também de Gonçalves Dias (neste poema, ela abordou as partes I, II, III e IV. Na parte I, a poeta ampliou as estrofes, mas seguiu a rima AABCCB; na parte II, ela mudou métrica e rima, ampliou as estrofes com versos de onze sílabas intercalados com de quatro ABCB; na parte III, as estrofes têm vários números de versos treze, quatro e seis, e são decassílabos sem padrão de rima; na IV, as estrofes têm diferentes números de versos, mas todos de cinco sílabas e sem padrão fixo de rima). Após, "Coração escravo" - em diálogo com "Navio Negreiro", de Castro Alves (I- onze estrofes e quatro versos decassílabos ABCB; II- quatro estrofes de dez versos com sete sílabas ABABCCDEED; III- uma estrofe de doze sílabas AABCCB; IV- seis estrofes de seis versos intercalando sílabas em dez e seis com rimas AABCCB; V- nove estrofes de sete sílabas ABCBDDEFFE; VI- três estrofes de oito versos decassílabos ABABABCC). Por fim, "Jogo de cintura" - em diálogo com "Língua Portuguesa", de Olavo Bilac (dois quartetos ABBA e dois tercetos CDC-EDE). Além das releituras, Menasché apresenta mais três apêndices poemas: apêndice A - "Beleza não põe mesa? ", onde novamente 'brinca' com Olavo Bilac; apêndice B - "Olhas para outro lado", onde se inspira em Gonçalves Dias e, apêndice C, onde elabora 'dois poemas-para-poetas', "Para João Cabral de Melo Neto" e "Para Olavo Bilac". Portanto, pela inusitada e criativa elaboração da obra, evidencia-se o sentido do

12 Cf.: http://dianamenasche.blogspot.com/search?updated$\min =2010-01-01$ T00:00:00-02:00\&updated-max=2011-0101T00:00:00-02:00\&max-results $=50$ 
próprio título, ou seja, o 'esqueleto' é uma alusão aos textos clássicos nos quais a autora se inspira; a releitura feita por ela neste processo contemporâneo de ressignificação e de uma nova roupagem é a 'carne' que ela acrescenta.

Essa interface forte entre nações e culturas nos poemas de Menasché, associada à investida autobiográfica da autora aqui e ali em alguns textos, remonta ao que Faist (2010) compreende por transnacionalismo: "transnationalism is often used both more narrowly - to refer to migrants' durable ties across countries - and, more widely, to capture not only communities, but all sorts of social formations, such as transnationally active networks, groups and organizations" (Idem, p. 9). ${ }^{13}$

$\mathrm{Na}$ Introdução, página nove da obra, Diana Menasché se inspira em Os Lusíadas, de Camões, e ressalta que este poema épico trata dos avanços da esquadra de Vasco da Gama, bem como das intempéries das viagens marítimas de exploração e descobrimento. Contudo, o que chama atenção é uma nota de ressalva que ela apresenta: "Ressalva - 0 poema que escrevi de modo algum pretende afiliar-se à ideologia de Os Lusíadas". Tal nota de ressalva, por si só, comprova a perspectiva pós-colonial de atuação da escritora, e mais do que isso, que sua releitura de fato é bem-vinda aos estudos pós-coloniais porque pretende emancipar e não objetificar o 'outro' pela 'conquista', no caso, o habitante do Novo Mundo. Neste ponto, não só a prática transnacional vem à tona, mas em especial a potencialidade da 'gnose liminar' de Walter Mignolo (2003), pois a Literatura se coloca a cargo de algo maior que si mesma, ou seja, promulga uma 'epistemologia liminar', com o saber advindo das margens em resposta aos centros mantenedores do poder. Assim sendo, sua nota de ressalva faz toda a diferença não somente no poema em destaque, mas em todo o restante da obra, uma vez que sua posição ideológica de emancipação discursiva e cultural se torna evidente. Segundo Barzotto (2014), surge, então, uma nova lógica de

13 Transnacionalismo é frequentemente usado de ambas as formas, mais estreitamente, para se referir aos vínculos duráveis dos imigrantes entre países e, mais amplamente, para capturar não somente as comunidades, mas todos os tipos de formações produção intelectual que pensa a colonialidade do poder através da modernidade, porém de forma livre, visando uma interseção das histórias locais mediante a imposição de novos projetos globais. Tal lógica nasce no entre-lugar porque configura a especificidade de um determinado lócus de enunciação, além de fluir dentro das línguas e das culturas. Por essa mesma ótica, essa nova lógica é essencialmente híbrida e transcultural, pois é construída no fluxo das 'contaminações' todas que geram sua existência, com vistas a compreender a diversidade e, principalmente, propagá-la no âmbito intelecto-social. Sendo assim, assume nova postura de 'estar no mundo' (híbrido) porque exerce a prática cultural em meio às identidades altamente intercambiantes.

Neste sentido, Mignolo (2003) avança e chama esta nova lógica de produção intelectual de genealogia do pensamento; basilar para que possamos construir, no universo intelectual, nossa epistemologia liminar ou gnose liminar, o que significa expor os pensamentos das modernidades coloniais sem a influência do outro (externo às nossas realidade e cultura) porque, em última instância, essa epistemologia promove o pensamento liminar, ou seja, 'um outro pensamento' que, além de ser livre dos jogos de influência e de poder, é genuinamente local, ímpar e sem precedentes, visto que é fruto de todas essas experiências, passadas e presentes, nas quais as histórias locais sobrevivem, mesmo tendo que absorver os projetos globais. Sendo assim, o pensamento liminar pode ser compreendido como o pensamento das margens, uma vez que há margens das margens e o centro (no formato eurocêntrico e norte-americano) já não é mais o mesmo porque se encontra fraturado e ocupado, ironicamente, pela 'periferia'. Se, por um lado, contribuir para a promulgação de uma epistemologia liminar significa emancipação intelectual e consciência de autonomia; por outro lado, significa agir contra a subalternização do conhecimento (BARZOTTO, 2014), o que se abstrai do posicionamento da própria escritora: "Em 'As

sociais, tais como redes ativas de transnacionalidade, grupos e organizações. (Tradução minha) 
Brasíadas', uma de minhas intenções foi abordar questões relativas à disseminação e à diversidade da Língua Portuguesa, refletindo tanto sobre o período dos descobrimentos quanto sobre as consequências dos movimentos de independência" (MENASCHÉ, 2013, p. 9). Portanto, o poema per se é uma proposta de gnose liminar.

O título do poema é instigante à observação, pois Diana substitui, veementemente, uma apologia lusitana (Lusíadas) para uma outra, totalmente tropical (Brasíadas); de antemão, o leitor percebe que o terreno a pisar é outro, ainda que todo o formato (esqueleto) do poema inspirador se mantenha em termos de estrofes e esquema rítmico.

$\mathrm{Na}$ primeira estrofe, o eu lírico reconhece a colonização portuguesa como princípio de uma história brasílica, uma vez que poesia e caravela se mesclam no 'descobrimento'; se o colonizador usou a caravela para desbravar além-mares, a poeta usa na contemporaneidade de sua releitura a poesia, genuinamente brasileira, fazendo jus ao título do poema, pois exalta as cores da bandeira: "Já com um vestido verde-amarelo, / aqui começo a minha história, que / não é minha, pois vem desde o Restelo, / [...] Ao Brasil!, a poesia nos leva, / ainda que não saiba a caravela." (p. 11). Compreendendo que o transnacionalismo, como uma perspectiva internacional, conecta indivíduos aos seus países de origem, o 'verde-amarelo' do primeiro verso enaltece o Brasil diante de um contexto múltiplo, Portugal - país colonizador e Estados Unidos - país onde reside a poeta, na possibilidade autobiográfica que alguns versos denotam. Assim, Mitchell apud Braga Martes \& Resende Fleischer (2003, p. 36) estabelece que

O conceito de transnacionalismo, em atitudes e ações, origina-se do reconhecimento dos cientistas sociais de que relativamente poucos imigrantes internacionais renunciam inteiramente à cultura e sociedade de suas nações de origem. De fato, sob as condições globais que têm emergido nos últimos cinquenta anos, cada vez mais imigrantes desejam e são capazes de manter vínculos com a sociedade onde nasceram.

Na terceira estrofe, o eu lírico chama a atenção para o peso da História a partir das memórias que a configuram, posto que afirma guardar "tantos séculos na memória! ". Sustenta, com isso, os argumentos de Halbwachs (2006) acerca da importância das memórias individual e coletiva para a ressignificação das narrativas, conforme já exposto no começo deste artigo. Sobre este potencial da memória, faz alusão à canção de Caetano Veloso e a um gênero literário típico do Nordeste do Brasil, ou seja, demarca significantemente aspectos culturais da nação brasileira, ao mencionar o líder do Movimento Tropicalista e a Literatura de Cordel: "Sim, os caracóis do meu cabelo / um cordel de narrativas aflora... / Assim que me apresento gentilmente / para dirigir-me a tão gentil gente". Na releitura do descobrimento, o eu lírico desvenda o Brasil com poesia e não assume a posição de colonizador, mas de autêntico sujeito brasileiro, 'um brasíada', já que desde o primeiro verso está imerso no verde-amarelo e narra a aventura como quem narra um cordel. Na quarta estrofe, porém, há um jogo de comparação entre Portugal e Brasil - "Dois mundos: Restelo e mata virgem [...] / Se lá em Portugal tem-se a miragem, / do lado de cá, chocante paisagem" (p. 12). Logo, os advérbios de lugar conotam o lócus de enunciação do eu lírico, lá Portugal, cá - Brasil. Com isso, percebe-se também a demarcação territorial escolhida, terras brasileiras. Ainda, o paradoxo entre substantivo abstrato (miragem) e substantivo concreto (paisagem) reforçam o grau de apego do eu lírico diante deste processo de escrita transnacional e emancipadora, pois para ele o projeto de conquista portuguesa fica no âmbito da miragem ao passo que sua existência brasíada fica no âmbito de uma 'real' paisagem.

Nesta jornada lírica de 'descoberta', a autora descontrói a colonização e invalida seus efeitos, uma vez que atua à revelia do sistema da colonialidade de poder, já mencionada. Enaltece, na sexta estrofe, a força e a pujança deste país tropical, retomando as cores da bandeira e o potencial de reação desta nação. "O verde-amarelo é quente, transforma / a tristeza em euforia" [...] "A vida passa por revolução" (p. 13). Neste sentido, o foco no Brasil enquanto lugar de potencialidades remonta aos aspectos configurados por Bauböck e Faist (2010) para o transnacionalismo e 
suas práticas diversas: i) há o cruzamento de fronteiras e o uso de políticas desterritorializadas; ii) tais práticas não estão, necessariamente, conectadas à uma consciência global; iii) nem sugerem uma progressão global de universalidade de direitos, posto que neste escambo de conexões globais e locais, pode-se enaltecer os valores locais, da origem, para justamente manter os vínculos com tal espaço, que podem, obviamente, ser concretos ou abstratos, como bem expressam os versos de Menasché em sua poética transnacional.

Neste estudo, eu seleciono as estrofes cujas temáticas refletem mobilidades culturais em trânsito e ressignificam a experiência da colonização em algo novo, notadamente emancipatório à luz da contemporaneidade. Apesar do poema se inspirar em Os Lusíadas, na oitava estrofe o eu lírico insere dois intertextos poéticos igualmente canônicos e os usa em prol de um conceito de brasilidade. "Cada ave gorjeia diferente" e "jorram lágrimas de Portugal" aludem, respectivamente, a "Canção do exílio", de Gonçalves Dias e a "Mar Português", de Fernando Pessoa; ou seja, até mesmo aqui o transnacional opera, já que há um poeta brasileiro e outro português em destaque interdito para afirmar que "Mesmo um aventureiro descontente" vai adaptar-se ao "surpreendente" (p. 1314). Por outro lado, na estrofe onze, a autora revela sua proposta poética, embebida de novos sentidos se comparada ao texto de inspiração; além de demarcar tempo e espaço narrativos. "Não tenho vontade de ser Camões / nem acho que cada um seja dois / Trago apenas algumas alusões / - escritas quinhentos anos depois". Ainda aqui (p. 15), o eu lírico se apropria dos versos de Camões para reverter a 'ousadia' daquele outro eu lírico, que se diz narrador mais importante que a Musa antiga: "Quando minha simples voz se levanta / nenhuma outra se afasta ou se espanta" em contraste com a estrofe três do Canto I de Os Lusíadas"14: "Cesse tudo o que a Musa antiga canta, / Que outro valor mais alto se alevanta".

A autora escreve, majoritariamente, em língua portuguesa, vez ou outra escreve em inglês ou em espanhol, mesclando esses idiomas a textos ou poemas em sua língua materna. Em diferentes ocasiões textuais, do blog aos livros, demostra apego pela língua portuguesa, inclusive nesta obra com o poema "Jogo de Cintura", o qual dialoga com o poema de Olavo Bilac, "Língua Portuguesa". Na estrofe quinze de "As Brasíadas", a poeta desenvolve uma espécie de homenagem à sua língua materna, situando-a explicitamente no contexto brasileiro: "Mas sonhos flamejantes ao espírito / português encheram os corações / e os papéis dos poetas da vez. Mérito / da língua que não se esgota em canções, / e se renova, entre o estilo homérico / e o estilo dos bélicos diapasões. / Quem quiser imitar será bem-vindo / no carnaval tropicaliente lindo!" (p. 16). Assume, deliberadamente, o entendimento de a língua é constructo cultural vivo de uma dada comunidade e, portanto, ela se renova. A autora, por sua, aproveita deste potencial de renovação e ela mesma o usa para interligar as premissas culturais e literárias que aborda, num vai-e-vem de saberes atualizados culturalmente e interpretados através do peso de nossa História e, por isso mesmo, permeados de traços de resistência, tal qual seu convite à imitação num 'palco tropicaliente' porque, como ela defende, a Arte imita a vida.

O que acaba de ser exposto acerca das estrofes oito e quinze, ressurge na estrofe vinte, de maneira resumida, quando o eu lírico novamente se posiciona como um poeta de sucede a Camões, em séculos, mas tem semelhante paixão pela língua materna: "Camões veio antes, e aqui eu venho / poetar sem receios. Aceito / o risco d' águas nunca navegadas / e o prazer das palavras bi-rimadas" (p. 18). Não obstante, mais uma vez condiciona sua lírica transnacional ao estatuto de 'descoberta ultramarina' por aceitar o risco de ‘águas nunca navegadas', neste caso, as águas de sua releitura. A estrofe vinte, de certa maneira, liga e conclui o que está anunciado nas estrofes oito e quinze, num desenho cíclico que aporta à arte da Poesia e ao uso da Língua Portuguesa em tal arte. Neste processo de atualização do discurso histórico proposto, o qual surge emancipatório, a memória 
coletiva é destacada para garantir, justamente, a consciência de uma epistemologia liminar atual, presente na estrofe seguinte, a vinte e um: "Pretéritos e futuros misturam-se / na minha história. Venho doutro ponto / no tempo." [...] Aqui reis tornaram-se presidentes / sem serem as nações independentes" ( $p$. 19).

$\mathrm{Na}$ estrofe vinte e quatro, o eu lírico divaga acerca do 'descobrimento' do Brasil e, neste momento, faz uso do hibridismo linguístico outrora mencionado como efeito dos movimentos migrantes e da globalização ${ }^{15}$. Tem-se, então, um transnacionalismo lírico-linguístico porque, se observado o contexto sócio-histórico e cultural dos versos, o trânsito e o vínculo se estabelecem entre Portugal, Brasil e Estados Unidos: "Será que houve índios esperando / os colonizadores com tapete vermelho?, capacho welcomeando / os gringos, uma party de sorvete?" (p. 20, grifos da autora). Atualiza o discurso a ponto de refletir acerca do neoimperialismo corrente, pois os portugueses, nesta estrofe, passam a ser os 'gringos', conotação comum dada aos norte-americanos, com percepção reforçada pelo uso da língua inglesa.

Um salto na História ocorre na estrofe vinte e sete e o eu lírico posiciona seus versos, dentro do panorama narrativo, no momento contemporâneo. "E como terá sido a independência? / No século XIX, o grito / nos anos 70, a violência / nos anos 90, acordo escrito..." Chama atenção para o suposto 'grito' da independência do país; para a violência da ditadura nos anos 70 (ou violência das guerras civis em colônias e ex-colônias portuguesas), e para o 'acordo' da independência de Macau nos anos 90. Nessa teia de países lusófonos, a autora usa da língua portuguesa para fazer a amarra. Bauböck e Faist (Idem, p. 11) defendem que o transnacionalismo inclui reciprocidade e solidariedade nos países de emigração e de imigração, com comuns empreendimentos em ambas as partes, com transferências de práticas e valores culturais e econômicos. Há, no bojo dessas ações, a construção de relações internacionais. Nesta estrofe em particular, percebemos um esforço do eu lírico para sublimar os efeitos da colonização portuguesa e unir os países lusófonos justamente de forma solidária, nesta teia internacional de relações. Fragmentos históricos são costurados nos versos, mas a mensagem é clara: a colonização foi um processo cruel aos que foram objetos dela. "Brasil presenciou a permanência / da família real sem muito agito / Povos africanos, e doutras partes / desdobraram-se em múltiplos infartes" (MENASCHÉ, 2013, p. 21).

$\mathrm{Na}$ vinte e oito, novamente a poeta enaltece a língua portuguesa como força motriz e elemento maior de união entre as ex-colônias de Portugal. Delega à língua a possibilidade de união e reciprocidade entre estes povos e, sobretudo, a capacidade de uma emancipação intelectual (gnose) por meio dela. Em todo o poema, esta perspectiva transnacional fortalece a concepção de uma epistemologia das margens pelo uso consciente, ressignificado e crítico da língua deixada pelo colonizador e sua capacidade de agência nos tempos atuais. "Tantas gerações, em quinhentos anos! / e cá'stamos co'a língua portuguesa / Angolanos ou caboverdeanos: / a gramática está posta na mesa! / Brasileiros, também moçambicanos: / tão livres, que nem a língua está presa. / Mesmo com governos independentes / vemos à fala dos antecedentes". Interessante perceber, no último verso da estrofe trinta, que o eu lírico sublinha seu apego à língua portuguesa ao mesmo tempo em que dá pistas do uso consciente e crítico que faz dela: "Amar a língua não é submissão!" (p. 22). Contudo, é na estrofe trinta e um (p. 23, grifo meu), em todos os seus versos, que a língua portuguesa passa de uma 'herança maldita' à concretude de um elemento transnacional e emancipatório.

Todos queriam a independência Mas não sabiam os limites dela.

A língua por si mesma é uma potência

E contra ela ninguém se rebela.

Talvez um caso de conveniência, Ou entrega total, por ser tão bela. Bem, quem no mundo é contra o português? Seguramente nenhuma de vocês!

${ }^{15}$ Cf.: Rajagopalan (2003). 


\section{Considerações finais}

Da estrofe trinta e três a trinta e cinco, um panorama multicultural é apresentado, retomando os elementos básicos do transnacionalismo, conforme Lacroix (2009). O eu lírico parece querer reunir nestas estrofes todos os povos afetados pela colonização portuguesa e, ao mesmo tempo, demonstrar como suas culturas sobreviveram. Lugares, línguas e comunas culturais são mencionadas; na estrofe trinta e três: "guarani, tupi, tétum, Tapajó, Junduaí"; na estrofe trinta e quatro: "umbundo, quimbundo"; e na trinta e cinco: "Maputo, Rondônia, Porto, Luanda, Porto Novo, Lisboa, Maranhão, Brasília, Macau”. O elemento de Lacroix mais evidenciado nestas estrofes é o de 'culturas híbridas', inclusive com alguns intertextos marcantes. Na trinta e três, a lenda do Saci é revivida: "Doidinho, samba numa perna só, / mostra que o Havaí não é aqui / e logo voa pelo Tapajó" (p. 24); em pouco e curtos versos muita cultura brasileira é apresentada ao leitor: a lenda do Saci, o samba, o rio e a cultura Tapajós e o intertexto com a música de Caetano Veloso, "Haiti". Outro intertexto na mesma estrofe faz alusão à Carmem Miranda: "Vou por na cabeça um abacaxi / e dançar ao sol em Jundiaí!". Na trinta e quatro, o foco é para uma África que vive no Brasil e uma crítica à escravidão: "Às vezes o laço se faz profundo / mais forte que se pode imaginar; / então, falando umbundo, kimbundo. / o Português presente no lugar" [...] Uma vez que se diga 'boa noite', / algo vive; não morre por açoite" (p. 24). Por fim, na última estrofe, o eu lírico se prende ao esplendor da língua portuguesa com o desejo de união dos povos lusófonos por meio dela, pré-anunciando uma harmonia entre "funk, frevo e fado". O poema termina da forma em que começou, quase que cíclico, convidando o leitor à uma aventura-descoberta poética por meio da língua portuguesa e, aqui também, a caravela é a própria Poesia: "Quem fala a língua pega a caravela / que uma parte do oceano revela" (p. 25, grifo da autora).
No poema analisado, os percursos transnacionais expõem culturas, hábitos, línguas e ideologias que são distintas em suas qualidades, mas que, por um lado, confluem-se pela força do trânsito cultural global e, por outro lado, interagem através da interface literária possível entre elas. Os versos de "As Brasíadas" não negam a História, mas revelam um Brasil independente e protagonista, cuja língua portuguesa se encontra modificada e hibridizada pela força da descolonização e pelo ativismo de um povo.

Neste contexto, transnacionalismo e gnose liminar atuam com similar propósito, o de permitir que as mobilidades culturais se efetivem numa via de intercâmbio, a fim de que o sujeito migrante mantenha seus laços e vínculos com sua terra natal, de maneira crítica e emancipatória, tal qual o próprio poema se apresenta ao leitor. Portanto, percebe-se com isso que a Literatura é um relevante instrumento para a promoção de uma epistemologia liminar e libertária.

\section{Referências}

ACHUGAR, H. Planetas sem boca: escritos efêmeros sobre Arte, Cultura e Literatura. Trad. Lyslei Nascimento. Belo Horizonte: Ed. UFMG, 2006.

ANDERSON, B. Comunidades imaginadas: reflexões sobre a origem e a difusão do nacionalismo. Trad. Denise Bottman. São Paulo: Companhia das Letras, 2008.

BARZOTTO, L. A. Pera, Prata e Porcelana. Revista Graphos UFPB, vol. 16, n², 2014, 88-98.

BAUBÖCK, R., and FAIST, T. (eds). Diaspora and Transnacionalism: concepts, theories and methods. Amsterdam, NLD: Amsterdam University Press, 2010. ProQuest ebrary. Web. Acesso em 11 Dez. 2015.

BRAGA MARTES, A. C., e RESENDE FLEISCHER, S. (eds). Fronteiras Cruzadas: etnicidade, gênero e redes sociais. São Paulo: Paz e Terra, 2003.

FAIST T. The volume and dynamics of international migration and transnational social spaces. Oxford: Oxford University Press; 2000.

FIGUEIREDO, E. Representações de Etnicidade: perspectivas interamericanas de literatura e cultura. Rio de Janeiro: 7Letras, 2010. 
HALBWACHS, M. A memória Coletiva. Trad. Beatriz Sidou. São Paulo: Centauro, 2006.

HALL, S. Da Diáspora: identidades e mediações culturais. Org. Liv Sovik. Trad. Adelaide Resende et al. Belo Horizonte: Ed. UFMG, Brasília: Rep. UNESCO no Brasil, 2003.

LACROIX, T. Transnationalism and development: the example of Moroccan migrant networks. Journal of Ethnic and Migration Studies, 35(10), 2009, 16651678.

LANDOWSKI, E. Presenças do Outro. Ensaios de sociossemiótica. Trad. Mary Amazonas Leite de Barros. São Paulo: Perspectiva, 2002.LE GOFF, J. História e Memória. Trad. Bernardo Leitão et al. 5a ed. Campinas: Ed. Unicamp, 2003.

LE GOFF, J. História e Memória. Trad. Bernardo Leitão

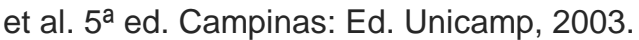

KRAUSE, J.; RENWICK, N. (eds). Identities in International Relations. Londres: Macmillan, 1996.

MARGOLIS, M. L. Goodbye, Brazil: emigrantes brasileiros no mundo. Trad. Aurora Neiva. São Paulo: Contexto, 2013.
MENASCHÉ, D. Traz o esqueleto que eu ponho a carne. Rio de Janeiro: Bolsa para Escritores da Biblioteca Nacional, 2013.

MIGNOLO, W. D. Histórias Locais - Projetos Globais: colonialidade, saberes subalternos e pensamento liminar. Trad. Solange Oliveira. Belo Horizonte: UFMG, 2003.

RAJAGOPALAN, K. Por uma Lingüística Crítica: linguagem, identidade e a questão ética. São Paulo: Parábola Editorial, 2003.

SANTIAGO, S. O Cosmopolitismo do Pobre: crítica literária e crítica cultural. Belo Horizonte: Ed. UFMG, 2004.

SAYAD, A. A Imigração: ou os paradoxos da alteridade. Trad. Cristina Murachco. São Paulo: EDUSP, 1998.

\section{COMO CITAR ESSE ARTIGO}

BARZOTTO, Leoné Astride. Transnacionalismo e Gnose Liminar em "As Brasíadas" (2013), de Diana Menasché. Signo, Santa Cruz do Sul, v. 41, n. 72, out. 2016. ISSN 1982-2014. Disponível em: <https://online.unisc.br/seer/index.php/signo/article/view/7271>. Acesso em: doi: http: //dx.doi.org/10.17058/signo.v41i72.7271. 